УДК 342.536

DOI https://doi.org/10.32849/2663-5313/2020.3.35

Василь Садовнік,

аспірант кафедри спеціальних юридичних дисциплін

Національного університету водного господарства і природокористування

\title{
ІНСТИТУТ ЗАКОНОДАВСТВА ВЕРХОВНОЇ РАДИ УКРАЇНИ У СТРУКТУРІ ПАРЛАМЕНТУ
}

Стаття досліджує правовий статус Інституту законодавства Верховної Ради України, його становлення, завдання і досягнення. Він є базовою установою науково-правового забезпечення законодавчої діяльності парламенту. Наголошено, що Інститут пройшов декілька етапів реорганізаиії, враховуючи як начіональну спеиифіку і традииіі розвитку парламентаризму, так $і$ зарубіжний досвід. Підкреслено, що знаковим стало реферування 2002 року, коли на зразок Дослідницької служби Конгресу СШІА підрозділи Інституту законодавства було сформовано за функиіональним, замість галузевого, приниипом та структурно орієнтовано на виконання завдань дослідницької служби законодавчої інституціі.

Акцентовано увагу на важливій ролі в ефективності законотворчої роботи структурних підрозділів Інституту - наукових відділів, у складі яких можуть діяти сектори. До структури Інституту входить Українська школа законотворчості, оскільки вкрай важливим і нагальним є питання підготовки законотвориів, що давно практикується в європейських країнах. Керівні прачівники і спеціалісти Інституту є державними службовиями або науковими працівниками. Потужний науковий потенціал спрямований на досягнення єдиного результату - провадження парламентських процедур на високому фаховому рівні.

Визначення орієнтирів розвитку начіонального законодавства - пріоритетне завдання Інституту. Заклад завжди докладно аналізував і аналізує результати законодавчої діяльності попередніх парламентських скликань, а на основі цього аналізу робляться науково обгрунтовані прогнози, без яких також неможливе забезпечення ефективності законодавства. Крім того, основними завданнями є: 1) підготовка пропозииій щодо стратегї державної правової політики парламенту; 2) проведення порівняльних досліджень законодавства України та іноземних держав, проблеми приведення національного законодавства у відповідність із нормами міжнародного права; 3) підготовка та участь у розробленні проектів законів із найважливіших питань розвитку суспільства і держави, їх наукове обгрунтування; 4) проведення наукової експертизи проектів законодавчих актів України; 5) надання науково-методологічної та освітнвої допомоги парламентаріям, прачівникам Апарату Верховної Ради та органам місцевого самоврядування у здійсненні ними законодавчих та нормотворчих повноважень.

Ключові слова: наукова робота, дослідницька робота, планування, законотворчість, парламент, державне будівництво.

Постановка проблеми. За роки незалежності України прийнято тисячі законів. За цим «параметром продуктивності» законодавчої діяльності Верховна Рада України вийшла на рівень сучасних парламентів розвинутих демократичних держав. Разом із тим теорія і практика законотворчого процесу висувають численні вимоги щодо його вдосконалення як основного напряму розвитку сучасної правової системи України. Поліпшення процесу підготовки і прийняття законів має стати наслідком інтеграції зусиль законодавчої і виконавчої влади - з одного боку, і суспільства - 3 іншого. Цього вимагають наявні факти прийняття недостатньо якісних документів, які містять суттєві про- галини та положення, що суперечать одне одному.

Причини такої ситуації: невиправданий поспіх під час підготовки і прийняття законів, надмірна деталізація, що негативно впливає на іх «стабільність» і на реальне застосування законів на практиці; корпоративізація законотворчого процесу, пов'язана iз прийняттям законодавчих рішень на користь групових, корпоративних інтересів, тоді як закон має виражати загальну волю та загальні інтереси народу України.

На ефективність законотворчого процесу також впливає те, що він продовжує розглядатися у відриві від суспільної практики, нагальних інтересів і запитів більшості 
громадян. Про це свідчить стан українського законодавства, яке ще й досі $є$ невпорядкованим, має неузгоджену внутрішню систему $[1$, c. 5]

Значний потенціал у вдосконаленні законотворчості може мати Інститут законодавства Верховної Ради України. Створений на зорі незалежності нашої держави, він зарекомендував себе як високопрофесійна внутрішньопарламентська інституція.

Метою статті $є$ дослідження завдань Інституту законодавства Верховної Ради України, результатів його функціонування для вітчизняного конституційного будівництва.

Під час написання статті використовувалися теоретичні напрацювання таких авторів, як: О. Богашова, Т. Гладкова, О. Копиленко, Н. Лебедь, Н. Оніщенко, А. Ришелюк.

Виклад основного матеріалу. Апаратне реформування парламенту України на початку 1990-х років відбувалося на основі двох різновекторних тенденцій. Варто пам'ятати, що в 1990 році Україна ще входила до складу СРСР і, так чи інакше, враховувала бюрократичні орієнтири радянської правової системи. Була створена група наукових консультантів, яка підпорядковувалася безпосередньо Президії Верховної Ради УРСР. На цю групу покладалося стратегічне планування вирішення глобальних проблем державотворення в умовах утвердження суверенітету України, підготовка нової Конституції України. У процесі подальших реконструкцій апарату парламенту ця група перетворилася спочатку на науково-експертний відділ, а потім - на Головне науково-експертне управління.

Паралельно дедалі активніше реалізовувалася і друга тенденція, пов'язана зі становленням та активізацією широких контактів Верховної Ради України з Конгресом США Правову основу двосторонніх контактів становили декілька вагомих документів, один із яких - Договір про співробітництво Президії Верховної Ради України та Дослідницької служби Конгресу Сполучених Штатів Америки від 11 лютого 1993 року - безпосередньо стосувався співпраці між апаратами парламентів. Тоді ж розпочався й активний обмін делегаціями. Українці вивчали досвід і засади роботи парламенту США, американці - реалії нашого життя й перспективи впровадження їх досвіду парламентського функціонування.

Із 1994 року Інститут пройшов декілька етапів реорганізації, враховуючи як національну специфіку і традиції розвитку парламентаризму, так і зарубіжний досвід забезпе- чення законодавчої діяльності парламентів. Знаковим стало реформування 2002 року, коли на зразок Дослідницької служби Конгресу США підрозділи Інституту законодавства було сформовано за функціональним, замість галузевого, принципом та структурно орієнтовано на виконання завдань дослідницької служби законодавчої інституції. Тим більше, що аналіз зарубіжного досвіду доводить, що не існує усталених стандартів i структурно-організаційних форм парламентських служб [2, с. 5]. Ігнорування іноземного і міжнародного досвіду може поставити країну на шлях ізоляціонізму (замкнена правова система), що прямо суперечить загальносвітовим пріоритетам правового розвитку [3, с. 460].

Нині Інститут законодавства є базовою установою науково-правового забезпечення законодавчої діяльності Верховної Ради України. Його основними завданнями є: 1) підготовка пропозицій щодо стратегії державної правової політики парламенту; 2) розроблення наукових концепцій розвитку національного законодавства; 3) проведення порівняльних досліджень законодавства України та іноземних держав, проблеми приведення національного законодавства у відповідність із нормами міжнародного права; 4) підготовка проектів перспективних та поточних державних програм законопроектних робіт Верховної Ради України; 5) організація моніторингу ефективності чинного законодавства України та прогнозування наслідків його застосування; 6) підготовка та участь у розробленні проектів законів із найважливіших питань розвитку суспільства і держави, їх наукове обгрунтування; 7) проведення наукової експертизи проектів законодавчих актів України; 8) надання науково-методологічної та освітньої допомоги парламентаріям, працівникам Апарату Верховної Ради та органам місцевого самоврядування у здійсненні ними законодавчих та нормотворчих повноважень.

Як і будь-яка юридична діяльність, законотворча являє собою систему дій, спрямованих на правовий результат, системність яких передбачає їх взаємну узгодженість, єдність і послідовність. Вона здійснюється в рамках певних правових процедур і правил. I така процесуальна врегульованість покликана забезпечити створення якісного закону, який відповідав би реальним потребам держави та суспільства [4].

Важливу роль в ефективності законотворчої роботи відіграють структурні підрозділи Інституту - наукові відділи, у складі яких можуть діяти сектори. До структури Інституту входить Українська школа законотворчості, оскільки вкрай важливим і нагальним 
$\epsilon$ питання підготовки законотворців, що давно практикується в європейських країнах. Цей структурний підрозділ здійснює заходи з поліпшення професійної правової культури авторів законів, а також науковометодичне забезпечення такої роботи (видаються серії книжок «Бібліотека Української школи законотворчості», «Енциклопедія законотворчості», «Українська школа законотворчості»). Перспективними напрямками зазначеної діяльності є введення дистанційної освіти, запровадження системи навчання та підвищення кваліфікації у сфері законотворчості всіх суб'єктів законодавчої ініціативи [1, с. 12].

Керівні працівники і спеціалісти Інституту є державними службовцями або науковими працівниками (в тому числі ті, що працюють за контрактом).

Для дослідження окремих проблем із питань законодавства та законотворчої діяльності створюються тимчасові трудові (творчі) колективи та робочі групи.

При Інституті функціонує Вчена рада Інституту - колегіальний дорадчий орган управління науковою діяльністю Інституту. До її складу входять за посадою директор, його перший заступник, заступник, вчений секретар та інші наукові працівники Інституту.

В Інституті створюється спеціалізована вчена рада для захисту дисертацій за відповідними спеціальностями (п.п. 2, 4 Положення про Інститут законодавства Верховної Ради України) [5].

Такий потужний науковий потенціал спрямований на досягнення єдиного результату - провадження парламентських процедур на високому фаховому рівні. Співвідношення реальних компетенцій працівників щодо прийняття законодавчих рішень, їхня готовність та здатність до подолання постійно виникаючих протиріч шляхом проведення багаторазових консультацій і переговорів, пояснення та модифікацій власних позицій, взаємних поступок та компромісів сприяють формуванню ефективного наукового співтовариства.

Крім того, збільшення чисельності та різноманітності сфер компетенції парламенту вимагає розроблення та впровадження відповідних специфічних правових інструментів, притаманних конкретній сфері діяльності, вдосконалення наявних та пошуку нових правових механізмів, перегляду чинних процедур обробки матеріалу. Тому складна система Інституту законодавства Верховної Ради України є надзвичайно цінною для ведення виваженої професійної експертної роботи [6, с. 15].
Далеко не всі народні депутати є юристами за фахом, але слід сказати, що іноді і юридичної освіти недостатньо для якісного виконання своїх обов'язків парламентаріями. Більше того, не кожний юрист-практик може бути готовим до роботи з аналізу законодавчої ініціативи та розроблення законопроектів. Саме тому в нагоді стають допоміжні служби парламенту.

Інституту законодавства Верховної Ради України не порівнятися, звичайно, з потужним апаратом парламенту США, в якому працюють сотні юристів. Депутат ще на стадії розроблення законопроекту може звертатись до Бібліотеки Конгресу США, Дослідницької служби Конгресу та інших підрозділів парламентського апарату за допомогою. Що стосується інших країн, то основним «постачальником» законодавчої роботи до парламенту є уряд. У багатьох із цих країн один окремо взятий депутат права законодавчої ініціативи не має, і тому в них зазвичай немає і спеціальних парламентських служб, які б допомагали депутатам готувати законопроекти.

Структура Інституту законодавства Bерховної Ради України запобігає намаганням приватного втручання в хід законотворчості з боку окремих парламентаріїв чи інших зацікавлених осіб. Цінність висновків його працівників полягає в тому, що висловлюється професійна колективна позиція на основі аргументованих положень, а не та, що може бути сформована в результаті неофіційного лобіювання з окремими фахівцями [7].

Використовуючи налагоджений із парламентськими комітетами зворотній зв'язок, Інститут здійснює наукові дослідження 3 огляду на конкретні запити законотворчої діяльності. Такий аналіз виконується за тематичними блоками, а його результат надається профільному комітету у відповідності з планами роботи комітетів парламенту і заходами, які вони передбачають реалізувати. Крім того, Інститут завжди прагне максимально враховувати будь-які індивідуальні звернення парламентаріїв, пов'язані 3 безпосереднім виконанням їхньої професійної діяльності. Це стосується найширшого кола питань - від експертизи законопроектів та безпосередньої роботи народних депутатів із громадянами аж до конкретного творчого пошуку [2].

Визначення орієнтирів розвитку національного законодавства - пріоритетне завдання Інституту. Квінтесенцією цього $€$ діяльність, спрямована на підготовку перспективних і поточних планів законопроектних робіт. Інститут на цій ниві має вагомі здобутки. Зокрема, такі плани неодноразово розглядалися і затверджувалися парламентом, як от, наприклад, «План законодавчого 
забезпечення реформ в Україні» 2015 року, в якому за галузевим принципом було представлено законодавчі орієнтири розвитку держави та суспільства. Інститут працював над Перспективним планом законопроектно роботи Верховної Ради України дев'ятого скликання з урахуванням останніх змін до Регламенту парламенту, а також готував поточний План на 2020 рік.

Інститут завжди докладно аналізував і аналізує результати законодавчої діяльності попередніх парламентських скликань, а на основі цього аналізу робляться науково обгрунтовані прогнози, без яких також неможливе забезпечення ефективності нашого законодавства. Інститутом започатковано великий дослідницький проект «Цифрова Україна: правові аспекти» як своєрідний орієнтир для визначення правової моделі електронної держави.

Упродовж багатьох років Інститут є ініціатором загальнонаціональних дискусій і публічного обговорення питань нормотворчості, організовуючи конференції, науковопрактичні семінари, круглі столи, експертн слухання тощо. Їхньою специфікою є те, що залучають якнайширшу аудиторію 3 усіх зацікавлених сторін - народних депутатів України, працівників органів державної влади та місцевого самоврядування, науковців, фахівців-практиків, представників громадськості та 3МІ [2]

Досягнення Інституту у практичній площині роботи парламенту є разючими. Так, негативні наслідки має відсутність у Верховній Раді України Національного реєстру законодавчих пропозицій, але проект Положення про реєстр розроблений Інститутом законодавства. Цей документ надасть можливість вчасно помітити та ліквідувати неузгодженості і суперечності між проектами, дублювання, прогалини, обрати найефективніші пропозиції, забезпечити необхідний контроль за станом обговорення законопроекту в парламенті, сформувати передумови аналітичної діяльності щодо перспектив та основних напрямків розвитку законотворчості [1, с. 9].

Крім того, Інститут розробив концепцію Державної програми моніторингу законотворчої діяльності. Така дія продиктована необхідністю дослідження ефективності дії чинного законодавства і законотворчого процесу в цілому і потребою нормативного регулювання, а також розроблення методичних рекомендацій «Методологія здійснення моніторингу законотворчої діяльності», в яких повинні бути визначені критерії оцінки ефективності дії законів. Слід забезпечити координацію й уніфікацію зазначеної діяльності з їх обов'язковим законодавчим закріпленням. Доцільно було б передбачити прийняття цієї Державної програми, що визначила б головні параметри, шляхи розвитку законодавства, умови створення структурних підрозділів у всіх органах державної влади, які б аналізували ефективність дії законів за своїми напрямками, моніторили концепції законопроектів та проводили їх моніторингову експертизу, а також здійснювали моніторинг у процесі систематизації законодавства. Важливою у цьому напрямку стала Постанова Верховної Ради України від 12 січня 2007 р. № $601-\mathrm{V}$ «Про утворення Тимчасової спеціальної комісії Верховної Ради України для вивчення питань аналізу стану додержання Конституції та законів України в нормотворчій та правозастосовчій діяльності державних органів, посадових осіб, інших суб'єктів владних повноважень».

Загальновідомо, що одним 3 основних показників ефективності законотворчого процесу є стан чинного законодавства. Відсутність довгострокових, скоординованих планів розвитку законодавства призводить до певних недоліків у вигляді розрізнених, неузгоджених, суперечливих правових норм, що складають правовий масив держави. Іноді прослідковується відсутність державного інтересу, який має пронизувати всю систему законодавства. Окрім відсутності скоординованого на перспективу плану законодавчих робіт, існує більш глибока причина - відсутність багаторічного стратегічного плану соціально-економічного розвитку країни [1, с. 11]. Такі напрями діяльності завжди знаходяться в полі зору Інституту. Головне - щоб органи державної влади розуміли необхідність подолання такої негативної практики державотворення і змогли спрямувати зусилля фахівців не лише Інституту законодавства на усунення прогалин.

\section{Висновки}

Упродовж багатьох років Інститут законодавства Верховної Ради України є базовою установою науково-правового забезпечення законодавчої діяльності. Структурні підрозділи - наукові відділи, у складі яких можуть діяти сектори, Українська школа законотворчості, задіяні в підготовці законопроектів, планів законотворчої роботи, навчанні самих законотворців, як це давно практикується в європейських країнах. Інститут здійснює заходи з поліпшення професійної правової культури авторів законів, а також науковометодичного забезпечення такої роботи. Потужний науковий потенціал спрямований на досягнення єдиного результату - провадження парламентських процедур на високому фаховому рівні. 


\section{Список використаних джерел:}

1. Копиленко О., Богачова О. Законотворчий процес: стан і шляхи вдосконалення. Наукові записки Інституту Верховної Ради України. 2010. № 1. С. $5-15$.

2. Поєднуючи зусилля учасників процесу законотворення. Голос Украйни. 20 грудня 2019 року URL: http://www.golos.com.ua/ article/325560.

3. Порівняльне правознавство (правові системи світу) / відп. ред. О. В. Зайчук, наук. ред. Н. М. Оніщенко. Київ : Парламентське вид-во, 2008. 485 с

4. Лебедь Н. В. Законотворча діяльність як правова категорія. Державне управління: удосконалення та розвиток. 2010. № 9. URL: http:// www.dy.nayka.com.ua/?op=1\&z=189.
5. Положення про Інститут законодавства Верховної Ради України від 4 серпня 2003 року, затв. розпорядженням Голови Верховної Ради України. URL: https://zakon.rada.gov.ua/laws/ show $/ 770 / 03-\% \mathrm{D} 1 \% 80 \% \mathrm{D} 0 \% \mathrm{~B} 3$.

6. Гладкова Т. Проблеми законотворчого процесу в Європейському Союзі. Науков записки Інституту Верховної Ради України. 2010 № 1. С. $15-20$.

7. «Ми намагаємось змоделювати, проаналізувати і спрогнозувати наслідки від ухвалення законопроекту: що піде на користь, а що завдасть шкоди», - Заступник керівника Науково-експертного управління Апарату Верховної Ради України Ришелюк Андрій Миколайович. Прес-служба Верховної Ради України. 26 січня 2016 року. URL: https://rada.gov.ua/print/123129.html.

The article examines the legal status of the Legislation Institute of Verkhovna Rada of Ukraine - its formation, tasks and achievements. It is the basic institution of scientific and legal support of the legislative activity of the Parliament. It was emphasized that the Institute has undergone several stages of reorganization, taking into account both the national specificities and traditions of parliamentary development, as well as foreign experience. 2002 was marked by the fact that, like the Congressional Research Service, units of the Legislation Institute were formed on a functional rather than a sectoral, principle, and structurally oriented basis to fulfill the tasks of a legislative institution's research service.

Emphasis is placed on the important role in the effectiveness of the lawmaking work of the structural divisions of the Institute - the scientific departments within which sectors can operate. The structure of the Institute includes the Ukrainian School of Lawmaking, as it is of utmost importance and urgency to prepare lawmakers, which has long been practiced in European countries. The Institute's specialists are civil servants or researchers. Powerful scientific potential is aimed at achieving a single result - conducting parliamentary procedures at a high professional level.

Defining the guidelines for the development of national legislation is a priority of the Institute. The institution has always thoroughly analyzed and analyzes the results of the legislative activity of previous parliamentary convocations, and based on this analysis, scientifically sound forecasts are made without which it is also impossible to ensure the effectiveness of legislation. In addition, the main tasks are: 1) preparation of proposals on the strategy of the state legal policy of the Parliament; 2) conducting comparative studies of the legislation of Ukraine and foreign countries, the problem of bringing national legislation into conformity with the norms of international law;3) preparation and participation in the drafting of lawes on the most important issues of development of society and the state, their scientific substantiation; 4) conducting scientific examination of draft legislation acts of Ukraine;5) providing scientific, methodological and educational assistance parliamentarians, employees of the Verkhovna Rada and local self-government bodies in the exercise of their legislative and normative powers.

Key words: scientific work, research work, planning, lawmaking, parliament, state building. 